Western University Scholarship@Western

Centre for the Study of International Economic

Centre for the Study of International Economic

Relations Working Papers

Relations

1982

Price and Quantity Rigidities in Adjustment to Trade Policy Changes: Alternative Formulations and Initial Calculations

John Whalley

Randy Wigle

Follow this and additional works at: https://ir.lib.uwo.ca/economicscsier_wp

Part of the Economics Commons

Citation of this paper:

Whalley, John, Randy Wigle. "Price and Quantity Rigidities in Adjustment to Trade Policy Changes: Alternative Formulations and Initial Calculations." Centre for the Study of International Economic Relations Working Papers, 8208C. London, ON: Department of Economics, University of Western Ontario (1982). 
CENTRE FOR THE STUDY OF INTERNATIONAL ECONOMIC RELATIONS

WORKING PAPER NO. $8208 \mathrm{C}$

PRICE AND QUANTITY RIGIDITIES IN ADJUSTMENT TO TRADE POLICY CHANGES: ALTERNATIVE FORMULATIONS AND INITIAL CALCULATIONS

John Whalley and Randy Wigle
Department of Economics Library

MAY $12198 ?$

University of Western Ontario

This paper contains preliminary findings from research work still in progress and should not be quoted without prior approval of the author.

DEPARTMENT OF ECONOMICS

THE UNIVERSITY OF WESTERN ONTARIO

LONDON, CANADA

N6A 5 C 2 


\title{
Price and Quantity Rigidities in Adjustment to Trade Policy Changes: Alternative Formulations and Initial Calculations 1
}

\author{
John Whalley \\ Economics Department \\ University of Western Ontario
}

and

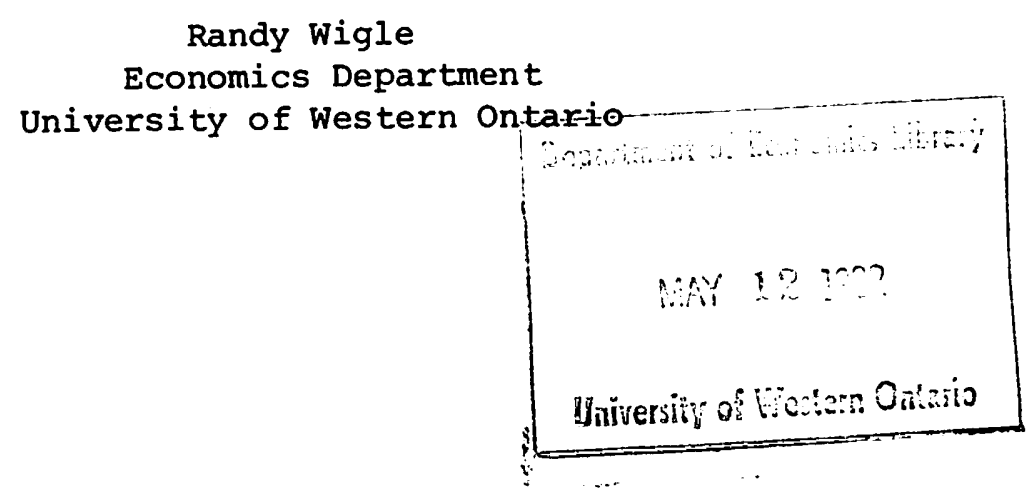

April, 1982

${ }^{1}$ paper to be presented at the In ternational Economics Association Conference on "Structural Adjustment in Trade Dependent Advanced Economies", Stockholm, August 2-6, 1982 . 
I. Introduction

In this paper we examine adjustment to trade policy changes in the context of a recently formulated seven region numerical general equilibrium model of world trade due to whalley (1982). We evaluate possible short run adjustment costs in response to trade policy changes using an approach similar to that adopted by Cline et. al. (1978) in their analysis of the Tokyo Round Trade Negotiations. We examine different formulations in which the required long run price and/or quantity adjustments are prevented from occurring due to adjustment rigidities. We also relate our calculations to welfare and adjustment cost estimates for the U.S. from a multilateral tariff reduction by Baldwin, Mutti, and Richardson (1980).

We begin with the evaluation of short run adjustment costs from trade policy changes under the assumption that trade-displaced workers, i.e., those who must reallocate across industries between equilibria, face a uniform duration of unemployment. To simplify matters we assume full employment of capital during the adjustment period. The key issue is whether adjustment impacts more than offset any potential gains from trade liberalization. This is possible if short run adjustment costs outweigh the discounted present value of the long term gains in a comparison between long run equilibria. Both Cline et. al. (1978) and Baldwin, Mutti, and Richardson (1980) evaluate this possibility and conclude, though with sharply different quantitative estimates, that adjustment costs are insignificant compared to the long run welfare gains from trade liberalization. Our calculations indicate that this need not be the case.

Te then examine different formulations of long run equilibrium in the presence of adjustment rigidities. Following Brecher (1974) and Neary (1980) we examine cases where there is downward rigidity of the real wage. In these cases endogenously generated unemployment may result if trade liberalization 
occurs and protection is removed from a labour intensive industry. An alternative specification we also discuss is a variant on the specific factors model due to Jones (1978), in which capital is immobile between industries. As might have been expected, these alternative formulations change the evaluation of trade liberalization initiatives and affect the perspective that one has on the desirability of trade policy changes. In the text, we numerically evaluate the effects of various trade policy changes in the model for these different variants and discuss the policy implications of results.

II. Literature Discussion of Adjustment Rigidities

In the recent work by Cline et. al. (1978), and Baldwin, Mutti, and Richardson (1980) on impacts of trade policy changes in developed countries, explicit recognition is given to the adjustment issue. The treatment adopted is to assume that the long-run equilibrium corresponding to the new trade policies will be achieved after a transitional period. In both of these studies, adjustment costs are estimated using explicit measures of unemployment duration and changes in capacity utilization.

Baldwin, Mutti, and Richardson consider a 367 industry input-output model of the US. Fixed coefficient intermediate production is assumed and fixed labour and capital coefficients. Final demands are price endogenous with both final demands by the US for imports and export demands by foreigners depending on the appropriate import and export commodity prices. A multilateral tariff reduction reduces import prices to US consumers and increases import volumes both directly and indirectly through the input-output structure. The reduction also reduces tariffs abroad which increases US exports. No full employment condition appears in the model and both labour and capital use can either rise or fall from the trade policy change. The implicit assumption is that sufficient un or underemployment of both factors exists that increased factor demands can be met. Alternatively, unemployment arising from the policy change is treated as an addition to the existing pool of unemployed resources. 
Baldwin et. al. identify industries with contracting and expanding employment as a result of any trade policy change. Since unemployment is always present by assumption, employment contraction adds to unemployment while employment expansion reduces unemployment. They calculate the net change in total unemployment (unemployed times duration) and treat this as a once and for all adjustment cost. ${ }^{1}$ Average duration of unemployment is allowed to vary by industry due to differences in the demographic make-up of the labour force. Duration estimates are combined with the calculated changes of employment by industry to produce the net unemployment effect. A similar treatment is adopted for capital, with the net contraction of capital assumed to be idle for 18.5 days on a once-and-for-all basis.

Baldwin et. al. calculate static welfare gains accruing to the US from a $50 \%$ multilateral reduction in tariffs. They discount the flow of welfare gains using a $10 \%$ discount rate and conclude the value of long-term gains to the US from such a policy change is around $\$ 1.1$ billion using 1967 data. Their estimated adjustment cost is $\$ 0.037$ billion, and they conclude that long-term gains substantially outweigh short-term costs.

Cline et. al. use a similar structure to Baldwin et. al. but simultaneously consider 11 OECD countries plus the rest of the world, linked through foreign trade. Thus rather than explicitly writing an export demand function for the US, export demands are generated from the import demands of all other countries in the model.s The impacts of trade policy changes are evaluated with or without consideration of exchange rate changes necessary to maintain the original trade balance in each country. As in Baldwin et. al. no full employment conditions enter and total factor employments change in each region as trade policies change.

$I_{\text {This treatment is used even though the net addition to existing }}$ unemployment is calculated. As an underlying equilibrium in the presence of unemployment is being assumed, it would seem that a justification exists for treating this net addition as a recurring cost (or benefit if a contraction is involved) rather than a once-and-for-all effect. This would significantly increase the estimated adjustment cost. 
Although total factor income may change as a result of trade policy alterations, this change in income is not reflected in consumer welfare.

Using an international price-taking formulation for each country, they evaluate the net gains to each country from participation in multilateral trade policy reductions proposed in Tokyo Round negotiations. Among the cases they consider is that of full U.S. tariff-cutting authority (effectively a. 608 multilateral tariff cut), and for this case they evaluate long-term welfare gains and short-run adjustment costs. They reach a similar conclusion to Baldwin et. al. as to the relative size of the two effects but produce significantly different estimates of the absolute sizes involved.

In estimating adjustment costs they consider only labour adjustment, capital reallocations are ignored. Unlike Baldwin et. al., they do not consider the net addition to total unemployment, but compute the labour reallocation between industries required to achieve full adjustment. They calculate employment changes in expanding and contracting industries from the trade policy change, and since full employment is not assumed the maximum of the sum of expansions and the sum of contractions is used as the estimate of labour reallocated. They assume a mean unemployment duration of 31 weeks, citing Bales (1974) study of trade impacted workers under the Kennedy Round. The combination of duration and labour reallocation (in value terms) gives a once-and-for-all adjustment cost estimate of approximately $\$ 0.61$ billion, nearly twenty times the size of the estimate due to Baldwin et. al. To estimate the discounted present value of welfare gains they first generate an estimate of annual static gains in a similar manner to Baldwin et. al. They then multiply this by a factor of 5 to reflect an estimate they provide of 'dynamic' to 'static' welfare gains (dynamic gains refer 
to gains from increased competition, economies of scale and other factors excluded in the static calculation). They then discount the flow of gains at 58 to provide an estimate of the present value of welfare gains to the US from a 608 multilateral tariff cut of approximately $\$ 49$ billion; nearly fifty times the welfare gain estimate of Baldwin et. al.

Thus like Baldwin et. al., Cline et. al. conclude that long term welfare gains significantly outweigh short term costs, although their estimates of each component are dramatically higher.

While, to the best of the present authors' knowledge, these studies are the only two which provide calculations of adjustment costs based on explicit numerical models, the adjustment issue has also received attention at a theoretical level. In contrast to the procedures used by Baldwin et. al. and $\mathrm{Cl}$ ine et. al., the adjustment process can be portrayed as involving rigidities in either price or quantity adjustments accompanying the trade policy change, which affect the equilibrium achieved by the economy. Several variants on traditional equilibrium trade models exist incorporating these rigidities although none of these appears to have been investigated numerically. .

A well-known trade model incorporating rigid wages is that due to Brecher (1974) and has recently been re-examined by Neary (1980). In this formulation the assumption is made that the economy faces a downward rigid real wage. This is attributed either to government legislation or to trade union pressure. In the presence of a binding downward rigid real wage, trade policy changes lead to equilibrating changes in labour hired rather than real wages paid. The result is endogenously generated unemployment. 
A second model incorporating adjustment rigidities is the specific factors model developed by Jones (1978) and Mayer (1974) where capital is industry specific. In a traditional Heckscher-Ohlin model capital is treated as intersectorally mobile, although immobile across countries. In a specific factors formulation, capital is treated as specific to its current industry of use and is unable to reallocate across industries in response to a trade policy change. If one of the major effects of trade protection is to reallocate factors between manufacturing and service industries, then a major portion of the adjustment involving capital is prevented in a specific factors model. The potential gains from increased specialization following trade liberalization would thus be smaller than in a model with sectorally mobile capital.

A third formulation of adjustment rigidities is an extension of this specific actors model to an intertemporal dynamic sequence framework. In this approach, sometimes referred to as a putty-clay model, investments can be allocated to any industry in the economy. Once put in place, however, it becomes impossible to reallocate that capital to other industries. Reallocation of capital occurs through new investment, but if a reduction in capital use is required in any industry when trade policies change, the only way this can be accomplished is through depreciation. This approach has been recently used in analysis of adjustment to changes in US tax policies by Fullerton (1981) in estimating dynamic welfare gains from a removal of distortions in capital income taxation.

III. Adjustment Rigidities and the Welfare Impacts of Trade Policy Changes Before we describe the model we use to evaluate the variations in policy assessment from these different approaches, we briefly outline the main issues affecting the evaluation of trade policy changes through choice of model formulation. 
We begin with what we term the 'reallocation cost' approach (essentially the methods used by Baldwin et. al. and cline et. al.). The desirability of a trade policy change under this approach depends on the discounted present value of gains from the change less the short-run reallocation costs. The size of the labour adjustment costs depends on the size of labour reallocations, the duration of unemployment, and the discount rate used to evaluate the present value of the welfare gains. Baldwin et. al. consider adjustment costs to be determined by the net change in unemployment rather than the gross reallocation, as in cline et. al. Both consider the adjustment cost to be a once-and-for-all change rather than a recurring cost, even though in Baldwin et. al. the adjustment cost applies to the net change in "long-run" unemployment. The reallocation cost calculations produce a net gain because labour adjustments are small ${ }^{1}$. and welfare gains from tariff reductions are positive since price taking behaviour is assumed.

In the rigid wage models it can easily arise that the welfare gains from removing distortions in a trade policy change are more than offset by the resulting unemployment. Since in the rigid wage models trade policy changes may lead to unemployment, it follows that a withdrawal of protection

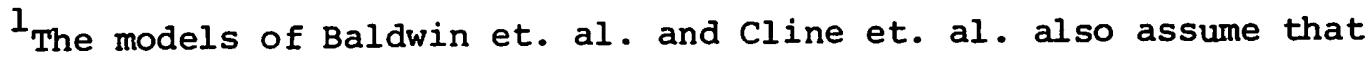
cross-price effects from the tariff change on the demand for non-traded goods are zero. As a result of this, they exclude a major avenue for adjustment to trade policy changes. A major reallocation in response to trade policy change will be a substitution between traded goods and non-traded goods such as services. These latter reallocations are captured by the numerical general equilibrium models of Deardorff and $S$ tern (1979) and Whalley (1982). This issue is significant because the calculation of adjustment cost will depend substantially on the volume of inter-sectoral employment changes. 
from a labour intensive industry will drive down the wage rate and generate unemployment. In contrast to a traditional full employment formulation, it can easily be the case that a small open price-taking economy can be made worse off as a result of trade liberalization. ${ }^{1}$

Relative to a traditional approach, the main difference from using a specific factors model with capital immobile between industries is to alter the calculated size of the gain or loss from a trade policy change. Since capital cannot be reallocated to all industries, some desirable reallocations will not be feasible. To this extent, trade policy changes will imply smaller gains (or larger losses) with sector specificity of capital than with freely mobile homogeneous capital.

$1_{A}$ related variant on this approach is the farris-Todaro (1970) model which we do not discuss here. In the Harris-Todaro model, instead of there being a rigid wage throughout the whole economy, a sector specific minimum wage occurs. The equilibrium condition in the model is that the probability of being employed at the sector specific minimum wage results in expected wages being the same in the two sectors. If there is intersectorally mobile capital it is possible in this model that it is desirable for the economy not only to remove trade protection policies but also to subsidize imports. This would be likely to occur if the sector specific minimum wage occurs in the import competing sector. The size of the import competing sector increases with protection and the level of unemployment correspondingly grows. 
IV. A Numerical General Equilibrium Model of Multilateral World Trade

In later sections we analyze the extent to which the evaluation of the desirability of a trade policy change may be significantly affected by the choice of model used to evaluate the change. A numerical general equilibrium model of multilateral world trade which has been formulated for uses in other contexts by Whalley (1982) is employed for this purpose. Into this we incorporate alternative formulations of the adjustment process. In this section we briefly outline the main features of this model. ${ }^{1}$

The general equilibrium model incorporates seven trading blocs reflecting major participants in world trade; the (nine-member) EEC, the U.S., Japan, Other Developed countries (including U. S. S.R. and Eastern Europe), OPEC, Newly I ndustrialized Countries (NICs), and Less Developed Countries (LDCs).

Six products produced in each bloc are considered and listed in

Table 1. Each of the first five goods are internationally traded with an assumed heterogeneity by trading area prevailing across production sources. The sixth commodity is non-traded for all blocs. The same commodity classification is used for trade, domestic production, and final demand data, with an approximate concordance used between different classification systems in basic data. Problems of data availability for all blocs on this classification plus the larger dimensionalities involved in solution for a multi trading bloc formulation have limited the model to six products and seven blocs; 42 products in total.

${ }^{1}$ A more detailed description of closely related earlier version of the model incorporating only the EEC, the U.S., Japan, and a residual rest of the world is given in Brown and Whalley (1980), and Whalley (1980). 
Table 1

Product Classification Used in the Model

SITC Headings

1. Agriculture and Food

$0+1$

2. Mineral Products and Extractive Ores

$2+4$

3. Energy Products (including oil)

4. Non-Mechanical Manufacturing

$5,6,8,9$

5. Machinery and Transport Equipment

7 (including Vehicles)

6. Construction, Services and other

None Non-Traded 
In the model, products are differentiated on the basis of geographical point of production as well as by their physical characteristics, with 'similar' products belng close substitutes in demand. Japanese manufactures are thus treated as qualitatively different products from US or EEC manufactures. This 'Armington' assumption of product heterogeneity by area is used both to accommodate. the statistical phenomenon of 'cross-hauling' in international trade data and to exclude complete specialization in production as a behavioural response in the model. This structure also enables empirically based import demand elasticities to be incorporated into the model specification.

A schematic flow chart depicting the model is given in Table 2. Production and demand patterns in each of the trading blocs revolve around the domestic and world price systems. Explicit demand functions are used which are derived from hierarchical CES/LES preference functions, and CES functions characterize production sets. Producers maximize profits and competitive forces operate such that in equilibrium all supernormal profits are competed away.

For each product the market price in the model is the price at point of production. Sellers receive these prices, purchasers (of both intermediate and final products) pay these prices gross of tariffs, NTB tariff equivalents, and domestic taxes; no transportation costs are considered. Investment flows, interest and dividends, and forelgn aid enter the world market system, with the second two of these being treated as income transfers. Foreign investment is treated as purchases of capttal goods by agents located in the country of source of capital funds. The difference between investment flows and merchandise trade is that the capital goods acquired are not repatriated to the country of location of the purchaser, but remain in the source country to generate income in future time periods. 
TABLE 2

FLOW CHART OF 7-REGION WORLD GENERAL EQUILIBRIUM MODEL

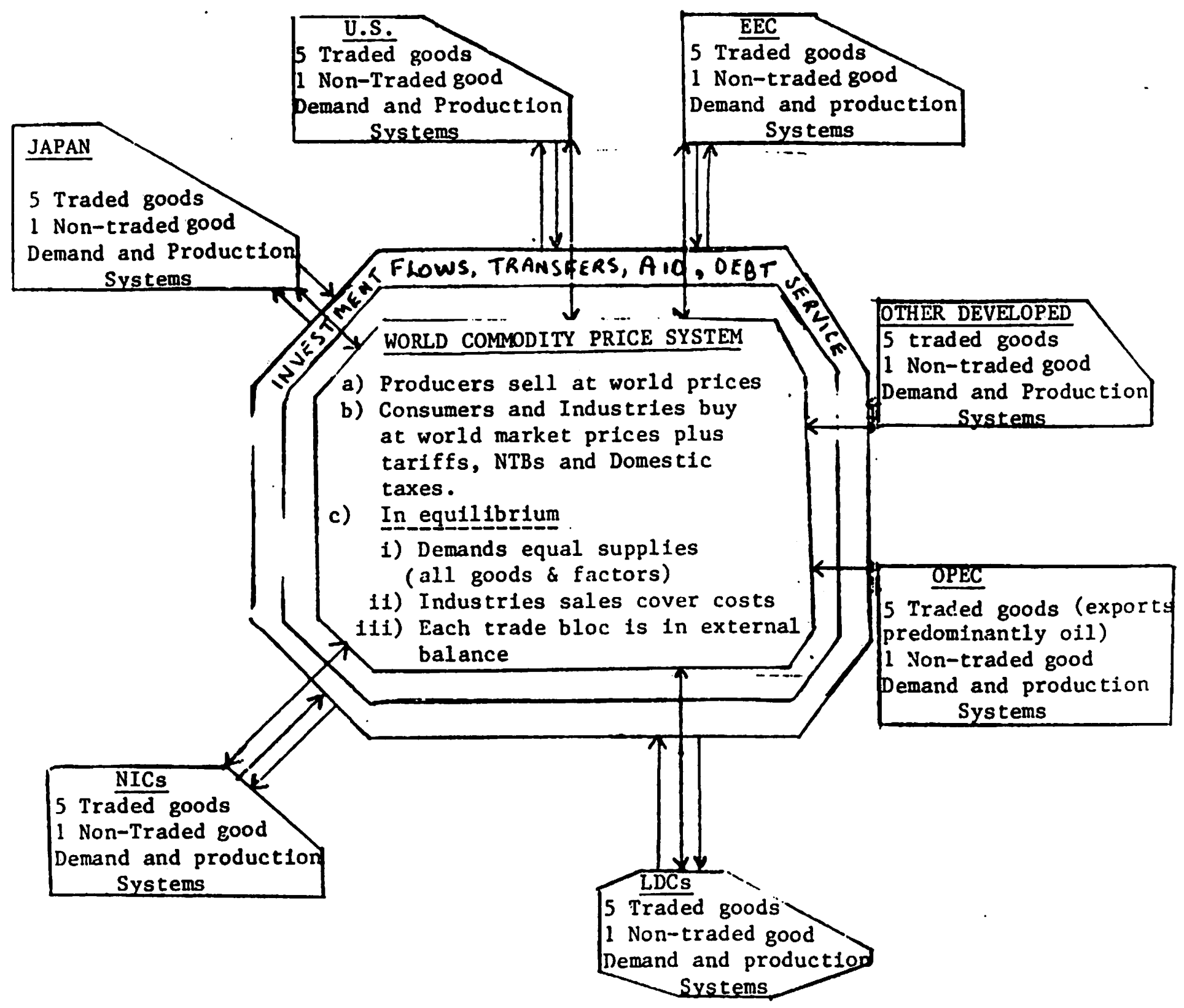


An equilibrium in the model is a situation where demands equal supplies for all products and in each industry a zero-profit condition is satisfied representing the absence of supernormal prodits. In equilibrium, a zero foreign external sector balance condition (including investment flows, dividends, interest and transfers) applies for each country.

The model uses hierarchical CES/LES functions on both the production and demand sides of the model. The elasticities of substitution in these functions are the parameters which determine price elasticities in goods and factor demand functions. Because of the Armington product heterogeneity assumption these elasticities also control import and export demand elasticities for any trading area.

Use of these nested functions enables empirical estimates of price elasticities in world trade to be incorporated into the model. These values guide parameter cholce for inter-nest elasticity values in the CES functions (i.e., between 'similar' products subscripted by location and production). The LES features in the hierarchy allow income elasticities in import demand functions to differ from unity.

The general equilibrium model is used for counterfactual equilibrium analysis following the procedures which have become widespread in recent applied tax and trade general equilibrium models. A flow chart outlining the procedure is given in Table 3. A worldwide general equilibrium constructed from 1977 data is assumed to hold in the presence of existing trade policies. The model is calibrated to the data set through a sequence of procedures which determine parameter values for the model functions consistent with the equilibrium restriction. Counterfactual analysis then proceeds for any specified policy change with a comparison between equilibria leading to the policy appraisal. 
$\underline{T a b l e} \cdot 3$

MODEL FLOW CHART OF APPLIED GENERAL EQUILIBRIUM ANALYSIS PROCEDURE IN US ING WORLD TRADE GENERAL EQUILIBRIUM MODEL

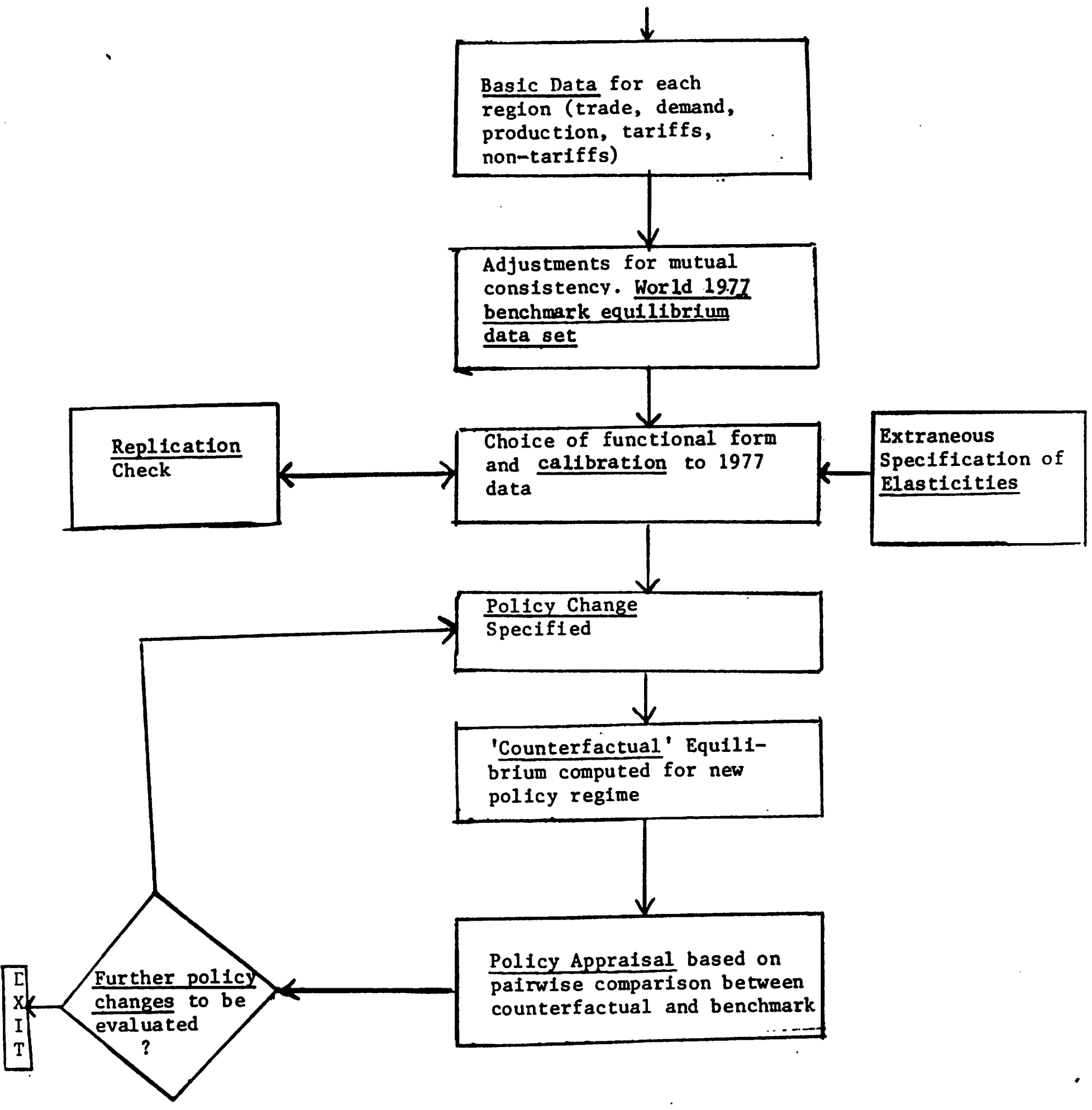


The calibration procedure involves first constructing a data set for a given year in a form which is consistent with the equilibrium solution concept of the model; a so-called benchmark equilibrium data set. Once assembled, parameter values for equations can be directly calculated from the equilibrium conditions using the calibration procedure described in Mansur and Whalley (1981). The model specification is then capable of reproducing the benchmark data as an equilibrium solution to the model, and comparative statics can be performed with the model by computing new equilibria for alternative policy regimes and comparing new and benchmark equilibrium data. The benchmark equilibrium data set constructed for this purpose has the properties of a worldwide competitive equilibrium in that demands equal supplies for all products, no profits are made in any of the domestic industries, and each region is in zero external sector balance.

Once specified, the model is solved for a new general equilibrium for a policy or other change using a Newton method involving an estimate of the Jacobian matrix of excess factor demands and government budget imbalances. In using this approach to evaluate the effects of alternative model variants on the evaluation of trade policy changes the benchmark equilibrium remains the same in all cases. For any given policy change a full equilibrium is computed, along with an equilibrium with the wage rate downward rigid at its value in the benchmark equilibrium, and an equilibrium with capital reallocation from the benchmark equilibrium values constrained. In each case a pairwise comparison is made between the benchmark and counterfactual equilibria to provide the evaluation of the policy change; all evaluations are thus with respect to the same initial starting point. 
V. Modelling the Adjustment Process in the General Equilibrium Model of World Trade

Three different approaches to modelling the adjustment process following a trade policy change have been considered in the model and applied to a number of alternative policy changes. The modifications to the basic general equilibrium model associated with each model variant follow:

\section{(i) Reallocation Cost Approach}

A full equilibrium corresponding to the trade policy change being investigated is computed in the usual way, and the change of employment in each sector determined. The labour reallocation cost is calculated as the total income of reallocated labour multiplied by the "duration" of unemployment for those who move between industries. We assume that all trade-affected workers remain unemployed for a period of 31 weeks, following the estimates of Bale (1974). This determines the short-run cost of adjustment to a trade policy change. The long-run welfare impact of the trade policy change is given by the present value of the static welfare changes. ${ }^{1}$ The net gain or loss is the long-run gain less the once and for all reallocation cost. We use a discount rate of 58 to calculate the present value of long-run welfare impacts. This uses a calculation of adjustment costs in the spirit of Baldwin et. al and cline et. al. to estimate the net gain or loss from a policy change.

\section{(ii) The Rigid Wage Approach}

The new equilibrium following a trade policy change is calculated in this instance incorporating a downward rigid wage rate in one region and the associated endogenous unemployment. The wage rental ratio in the region involved is constrained to be equal to or above the value associated with the benchmark equilibrium. Computational simplicity motivates considering the case where the rigid wage regime binds in only one bloc.

$1_{\text {This involves the calculation of the Hicksian equivalent variation }}$ for each region in the model when a policy change occurs. 
Instead of computing a set of factor prices and government revenues which clear the factor markets and yield a balanced government budget as in usual full equilibrium computations, in cases where the rigid wage binds we calculate the equilibrium level of unemployment of labour which satisfies the same conditions. This approach does not involve a separate calculation of the adjustment cost associated with the policy change. The estimate of the welfare gains or losses from any given policy change reflects the income loss from unemployment along with other effects such as the consumption gain from removal of a domestic distortion, and terms of trade impacts.

\section{(iii) Specific Factors Approach}

The specific factors approach as implemented involves the calculation of a full general equilibrium as in other applications of the model but where there are two non-substitutable types of capital. One type of capital is only used in manufacturing industries while the other is used only in non-manufacturing. The dimensionality of the price cum revenue simplex characterizing the model is augmented by one, and the two types of capital are considered as separate factors, whose factor markets are cleared by the corresponding factor price. As before, for reasons of computational simplicity factor specificity is limited to only one of the trading blocs in the model. This approach also does not involve a separate calculation of the adjustment cost of a trade policy change, but will involve a different estimate of welfare gains to each region from a given trade policy change. This follows since part of the reallocation of capital which could occur under the assumption of intersectorally mobile capital is no longer feasible. 
VI. Evaluation of Policy Changes

In this section we report the effect of some policy changes evaluated under the model formulations outlined above.

We analyze four different cases listed in Table 4: a unilateral abolition of US tariffs; a multilateral doubling of tariffs among GATT members; unilateral doubling of tariffs in the EEC; and finally the effects of a $50 \%$ multilateral tariff reduction by the developed country members of the GATT. In each case we evaluate the welfare impacts and terms of trade effects of the policy change in full long run equilibrium and then under the fixed wage and specific factors approaches. Annual welfare impacts are reported in terms of Hicksian equivalent variations in 1977 \$ bill. for each region. We use a $5 \%$ discount rate in calculating the discounted present value. From the first formulation we estimate adjustment impacts using the reallocation cost approach.

The first three policy changes are chosen because the rigid minimum wage is binding in each case, allowing us to compare the long run, the rigid wage, and specific factors equilibria. The analysis of a $50 \%$ multilateral tariff reduction among the GATT allows us to compare our estimate of reallocation cost to the labour adjustment costs of Baldwin et. al. and cline e. al.

Because prices, and hence terms of trade, are endogenously determined within the model, a unilateral abolition of tariffs will have two effects: a terms of trade effect against the abolishing country if tariffs are originally at or below an optimal tariff, with a domestic consumption gain (gain in consumer surplus) resulting from the elimination of the distortion between producer and consumer prices. Since tariffs in all of the developed countries in the model are all substantially below model optimal tariffs ${ }^{1}$, unilateral

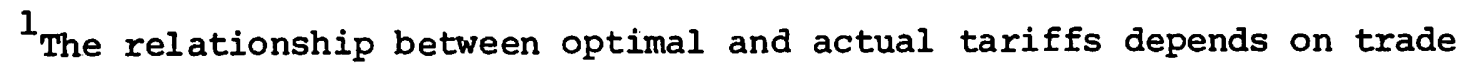
elasticities. The elasticities in the model imply optimal tariffs well in excess of the 1976 tariff rates used. 
$\underline{\text { Table } 4}$

Policy Changes Considered Under Alternative Formulations

Case 1: Abolition of US Tariffs:

Counterfactual equilibrium involves the U.S. tariff being set equal to zero.

Case 2: $\quad$ Tariffs in GATT Doubled

All tariff barriers in the EEC, the U.S., Japan and 0 ther Developed are increased by a factor of two for all commodities.

Case 3: Doubling of EEC Tariffs:

The EEC tariff on all commodities is doubled.

Case 4: 50\% Multilateral Reduction in Tariffs in

EEC, US, Japan, and Other Developed:

Tariffs are cut by one-half in the four developed regions in the model. 
abolition of a tariff implies a deterioration of the terms of trade. A welfare loss typically results, suggesting that "consumption" gains are substantially outweighed by terms of trade losses. The major gainers are the trading partners of the tariff cutting country.

In the rigid wage case, if the trade policy change implies a reduction of the real wage, some of the labour released by contracting industries is not re-employed by expanding industries. In the specific factors case, some of the desired reallocations which would be feasible under the full equilibrium assumptions are no longer feasible. The result of both of these is to reduce the ability of the economy to fully adjust to trade policy changes. This will reduce the gains or increase the losses associated with any policy change.

As a result of these same adjustment features, the effective elasticity of export supplies will be reduced, and for any given shift in the demand for exports, a smaller quantity response and larger price (terms of trade) effect would be expected. A reduction of the elasticity of export supplies will also imply a higher optimal tariff and, potentially, larger welfare gains arising from increases in tariffs.

Results from the three formulations are given in Tables 5, 6, 7 for the first three cases. Th $50 \%$ multilateral case is considered to compare the approaches to those of Baldwin et. al. and $\mathrm{Cline}$ et. al., and is reported on in Tables 8 and 9 .

\section{(i) Abolition of U.S. Tariffs}

Under full equilibrium assumptions U.S. terms of trade deteriorate $2.5 \%$ and annual welfare losses of 4.5 billion dollars (using 1977 data) result from a unilateral abolition of U.S. tariffs. The major gainers from such a policy are U.S. developed country trading partners, specifically the EEC, Japan and the Other Developed bloc. 


$$
\begin{aligned}
& \text { ำ } \\
& \text { y } \\
& \text { ต }
\end{aligned}
$$

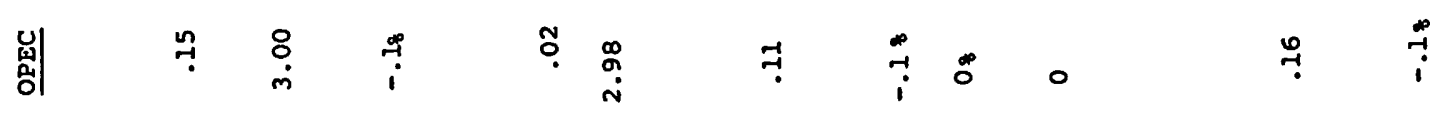

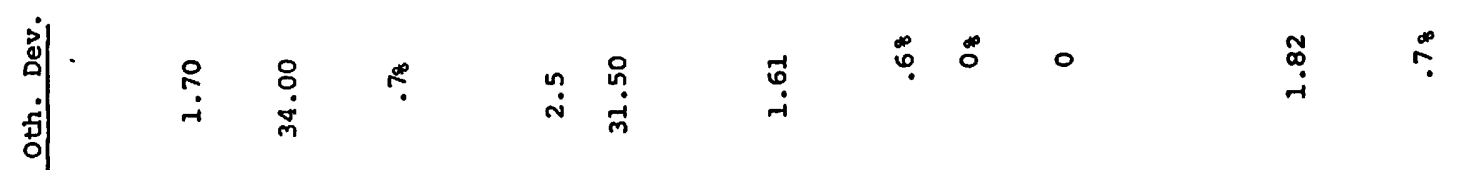

$$
\begin{aligned}
& \text { 1 } \\
& \text { ม } \\
& \text { ม1 }
\end{aligned}
$$

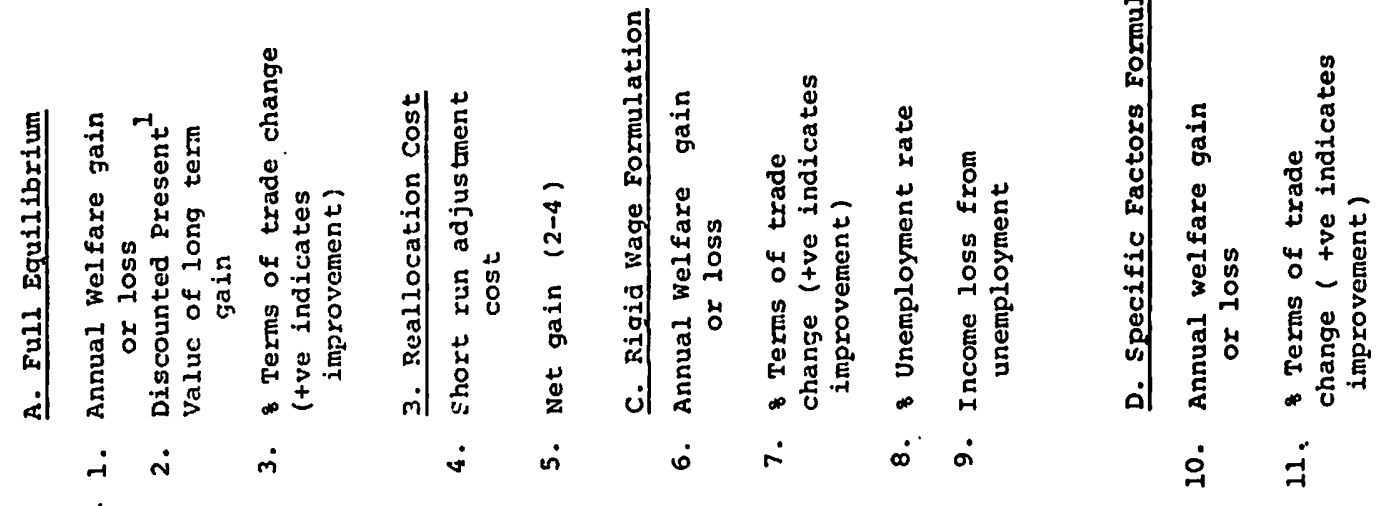

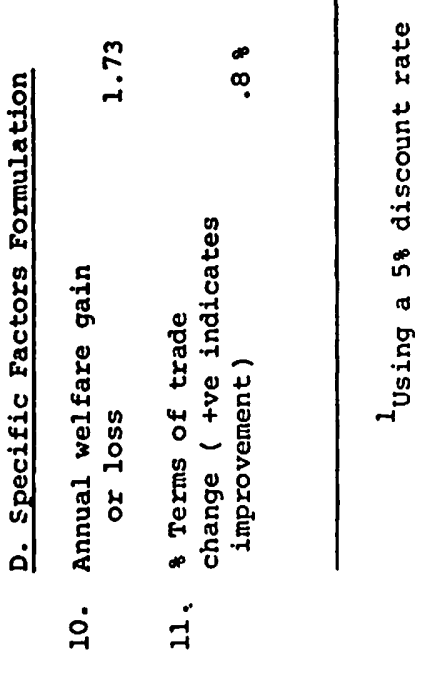


The reallocation cost to the U. S. implied by this policy change is not inconsequential. In fact, the annual welfare loss to the U.S. of $\$ 4.47$ billion is comparable to the once-and-for-all reallocation cost of $\$ 4.46$ billion. Reallocation costs are sharply higher than in both Cline et. al. and Baldwin et. al. et. al. since significantly larger labour reallocations result because of the substitution of labour between traded and non-traded goods industries. Interestingly the change is a losing proposition from a global viewpoint. The world's annual welfare gain from the policy change is $\$ .2$ billion, whose present value at 58 is $\$ 4$ billion. Taking account of the worldwide total labour reallocation cost of $\$ 8.63$ billion produces a loss of $\$ 4.83$ billion. Under the rigid wage formulation, losses due to the abolition of tariffs are more than doubled. This additional loss can be decomposed into a direct income loss of $\$ 5.2$ billion resulting from unemployment and additional losses attributable to the fact that a no tariff configuration is even further from the optimal tariff under the rigid wage regime.

In the case where manufacturing capital is sector specific in the U.S., welfare losses due to tariff abolition are also increased, and predicted larger negative terms of trade effects are seen. The increased welfare loss reflects a combination of the greater terms of trade loss and the reduced ability to substitute in production as trade policies change.

\section{(ii) Doubling of Tariffs in GATT}

A doubling of tariffs by GATT means increased tariffs primarily on manufactures. The countries who suffer most in full long run equilibrium are the U.S. and Japan; the terms of trade also move against these two blocs. This policy represents a substantial increase in protection between the largest trading regions in the model. The total annual welfare loss for the world in the absence of adjustment costs is $\$ 5.3$ billion. Discounted at $5 \%$ this loss is $\$ 106$ billion and with the inclusion of $\$ 26.3$ billion in reallocation costs the estimated loss to the world of such trade restrictions exceeds \$125 billion. 


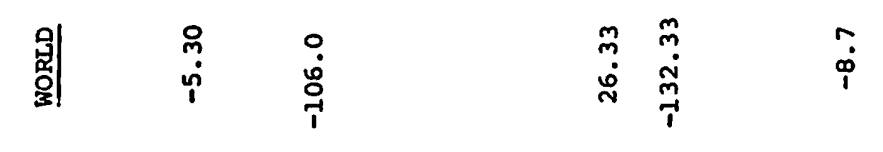

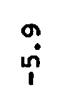

ป

$\because$

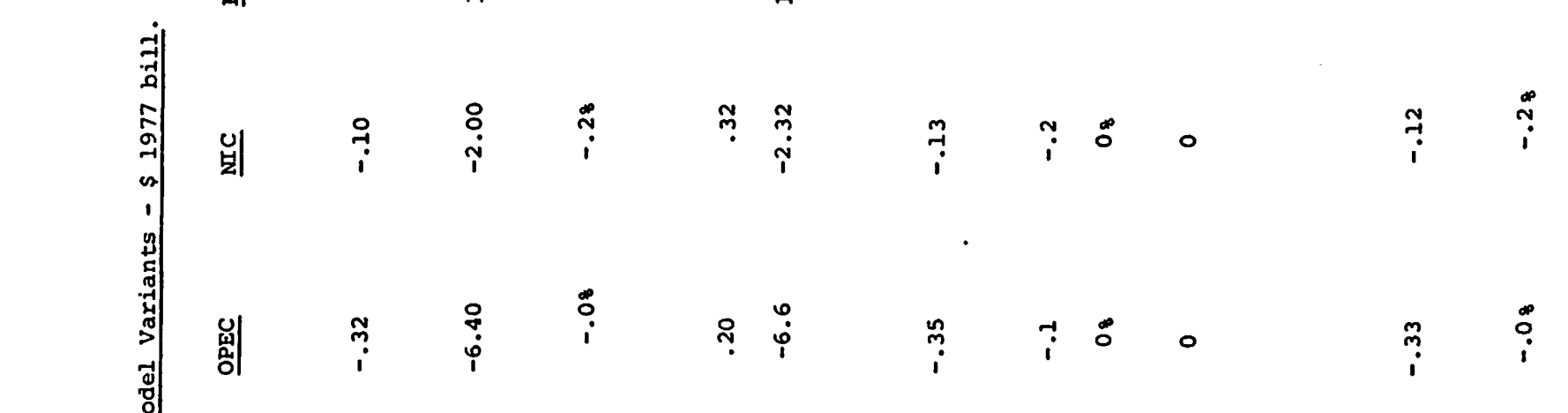

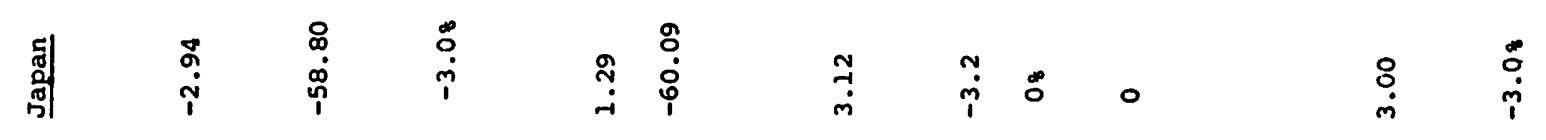

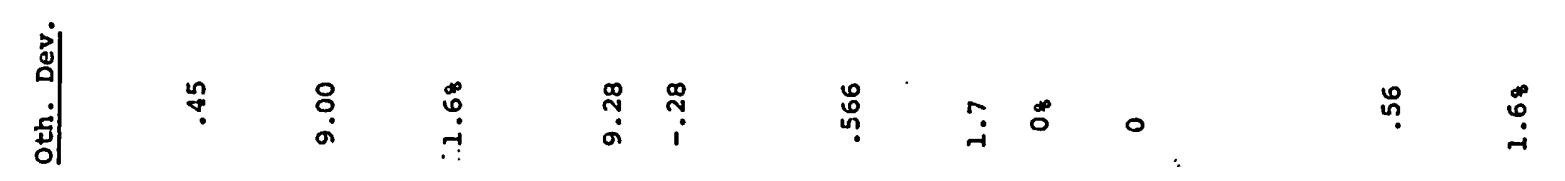

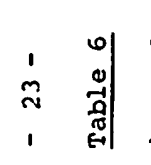

I

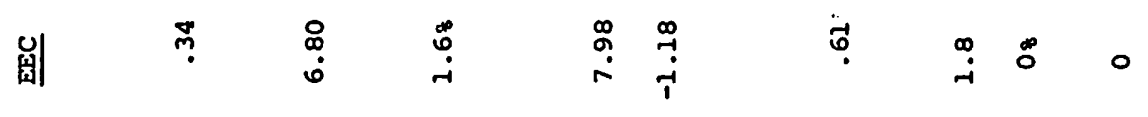
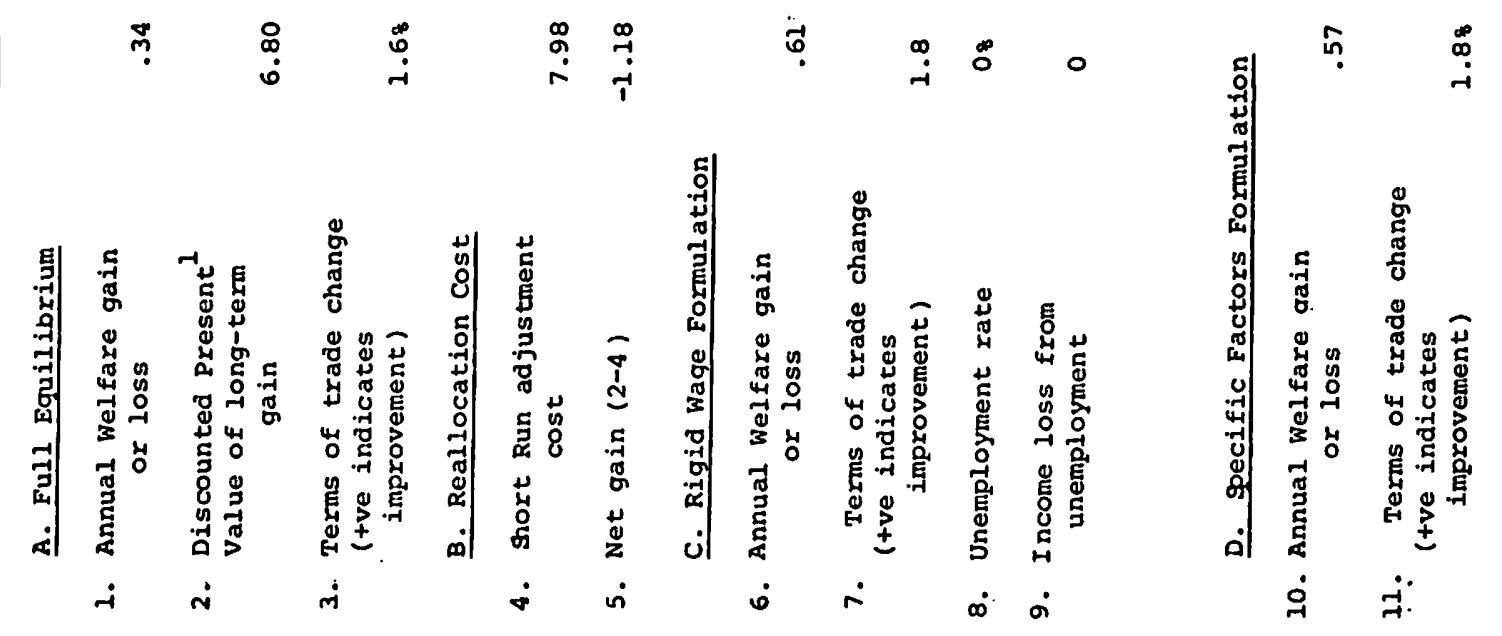


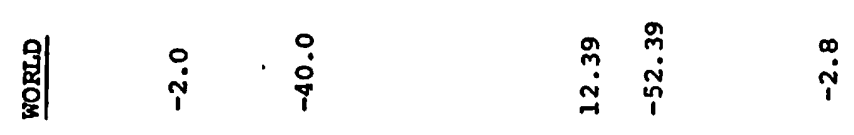

$\vec{\xi}$

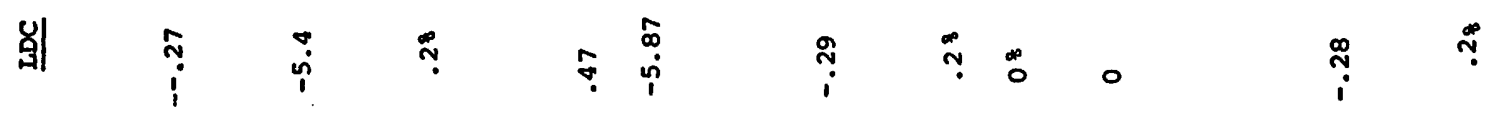

早

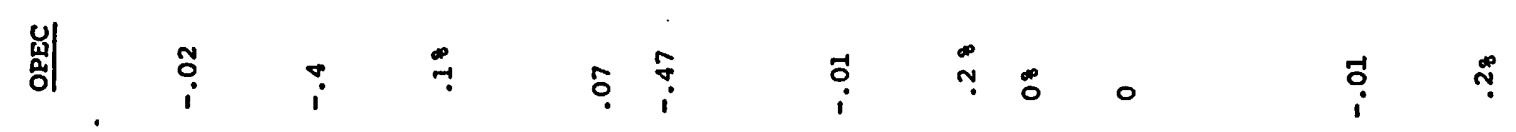

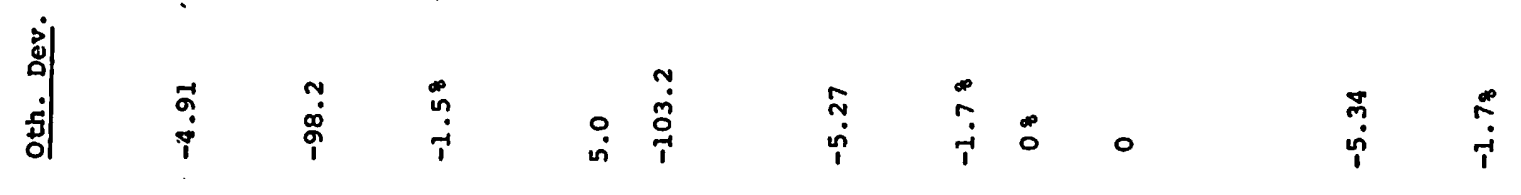

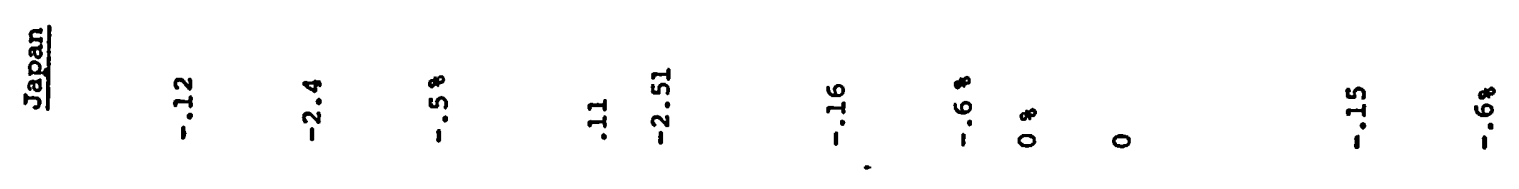

岁

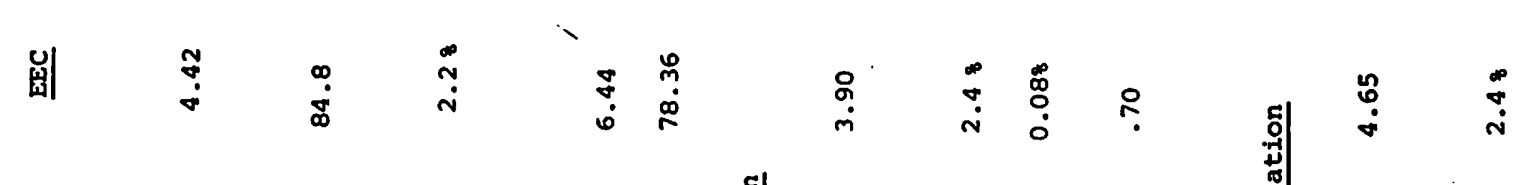

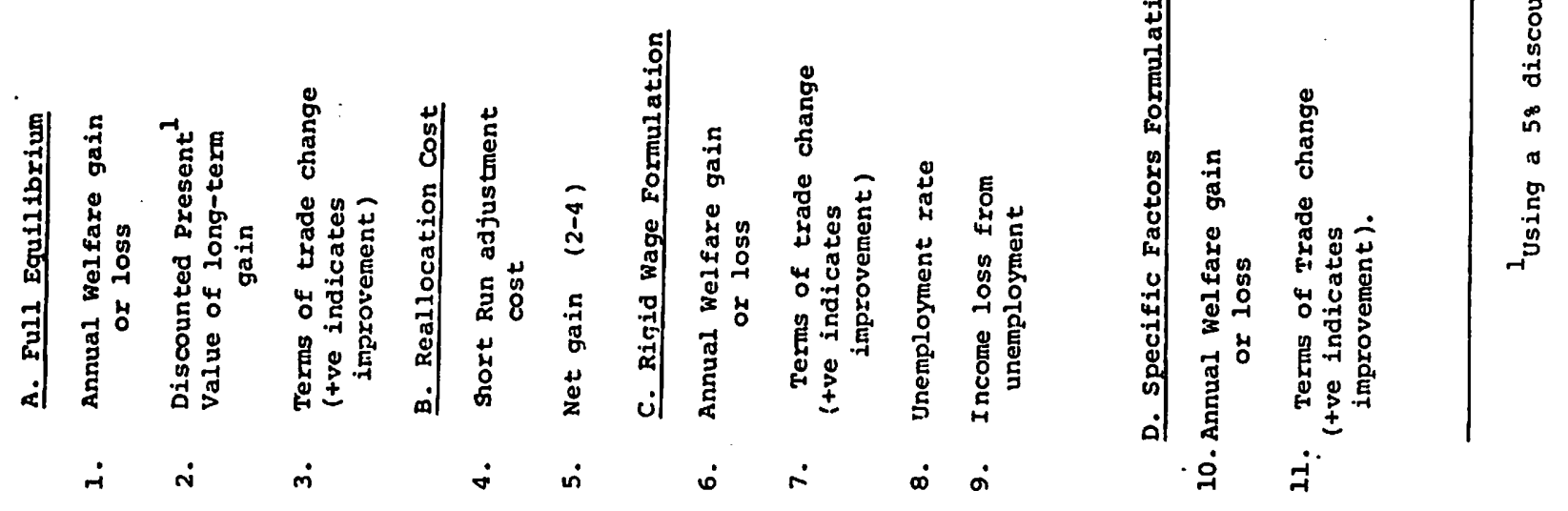


If a rigid wage is binding in the U.S., increased tariffs in developed countries imply an even heavier loss. Even though the rate of unemployment induced by the policy change is extremely small (four-tenths of one percent), the implied income loss is almost $\$ 2.5$ billion. When coupled with the decreased trade flows induced by reduced incomes in developed countries a welfare loss results almost double that calculated for full long run equilibrium.

If capital specificity exists in the U.S., welfare losses due to trade restriction are increased and the terms of trade deteriorate more, as expected. (iii) Unilateral Doubling of EEC Tariffs

A doubling of tariffs unilaterally by the EEC implies a move towards an optimal tariff (assuming no retaliation). The result is that the EEC's terms of trade improve as does welfare.

In this case the adjustment cost to the EEC of unilaterally doubling tariffs exceeds the annual welfare gain by more than 50\%. The presence of adjustment costs modelled this way reduces the incentive for countries to unilaterally increase protection.

In the face of a rigid wage in the EEC, the welfare gains brought about by increased tariffs are reduced by a small amount. This is because the increased positive response of the terms of trade caused by the decreased elasticity of export supplies dampens the direct income loss of unemployment to $\$ .7$ billion. As a result the welfare gain is only $\$ .3$ billion less than the welfare gain under full long-run equilibrium assumptions.

If capital is sector specific in EEC manufacturing, the terms of trade of the EEC appreciate more as tariffs rise, and the EEC gains more from the higher trade restriction in the presence of capital specificity. 
(iv) Multilateral Reduction of Tariffs by $50 \%$

in the EEC, US, Japan, and Other Developed

To generate results from the model which can be compared to those of $\mathrm{Cline}$ and Baldwin we also consider the case of a $50 \%$ multilateral reduction in tariffs by the EEC, the $U S$, Japan and Other Developed. Our findings are given in Tables 8 and 9.

Unlike the international price taking calculations of Baldwin and Cline, our estimates of the static welfare gains for the $U \subseteq$ in Table 8 are negative. This results from the fact that $U S$ terms of trade deteriorate by almost 18 . Our calculation of the labour reallocation cost associated with the policy change is significantly higher than that of cline et. al., which in turn, exceeds the estimate of adjustment cost of Baldwin et. al., by a factor of more than 10. As a result, our calculation of the net welfare effect of the proposed policy change is substantial and negative.

If a rigid wage were in place in the U.S., the calculated loss to the US in Table 9 from the policy change more than doubles, due to a substantial income loss due to unemployment. If the rigid wage was downward flexible in the medium term and unemployment decayed linearly over a 3 year period, the present value of the loss to the U.S. from such a policy evaluated at $5 \%$ would be $\$ 4.3$ billion.

In the presence of capital specificity in the U.S. manufacturing, static losses to the US are once again somewhat larger than under full long run equilibrium assumptions and the terms of trade deteriorate more.

\section{Policy Implications and Conclusions}

Although the trade policy measures considered here are unlikely to be options selected by policy makers, the results of our calculations do point to changed perspectives on trade policy evaluation under the three approaches to modelling adjustment outlined. 
Table 8

Impacts on the US of

$50 \%$ Multilateral Reduction of Tariffs

Comparison of Calculations

(All Figures in suS Billions) ${ }^{* *}$

\begin{tabular}{|c|c|c|c|c|c|}
\hline Calculation & $\begin{array}{l}\text { tic } \\
\text { fare } \\
\text { nge } \\
\text { sBil1.) }\end{array}$ & $\begin{array}{l}\text { PV } \\
\text { at } \\
5 \% \\
\end{array}$ & 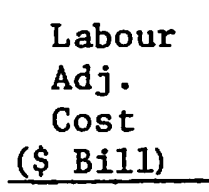 & $\begin{array}{l}\text { US } \\
\text { Net } \\
\text { Welfare } \\
\text { (\$ B Bill) } \\
\end{array}$ & $\begin{array}{l}\text { Ratio of } \\
\text { Total } \\
\text { Gains / } \\
\text { Loss } \\
\end{array}$ \\
\hline $\begin{array}{l}\text { Cline et. al. } \\
\text { (1974 data) }\end{array}$ & 2.45 & 49.1 & .61 & 48.5 & 81.0 \\
\hline $\begin{array}{l}\text { Baldwin et. al. } \\
\text { (1967 data) }\end{array}$ & .11 & 2.2 & .04 & 2.16 & 54.0 \\
\hline $\begin{array}{l}\text { Reallocation } \\
\text { Cost Approach } \\
\text { (1977 data) }\end{array}$ & -1.1 & -22.0 & 2.20 & -24.2 & -11.0 \\
\hline $\begin{array}{l}\text { Fixed Wage } \\
\text { (1977 data) }\end{array}$ & -2.9 & -58.0 & N/A & -58.0 & $\mathrm{~N} / \mathrm{A}$ \\
\hline $\begin{array}{l}\text { Specific } \\
\text { Capital } \\
\text { Factors } \\
\text { Formulation } \\
\text { (1977 data) }\end{array}$ & -1.5 & -30.0 & $\mathrm{~N} / \mathrm{A}$ & -30.0 & $\mathrm{~N} / \mathrm{A}$ \\
\hline
\end{tabular}

* Baldwin et. al. use 1967 data, all others 1977 data.

** All present values at $5 \%$, the value used by Cline et. al.

*** These results are for a 608 multilateral cut. 


\section{Table 9}

508 Multilateral Reduction of Tariffs in EEC, US, Japan, and Other Developed Bloc Impacts by Region

A. Annual Welfare Gains (EV's in \$ bill. 1977)

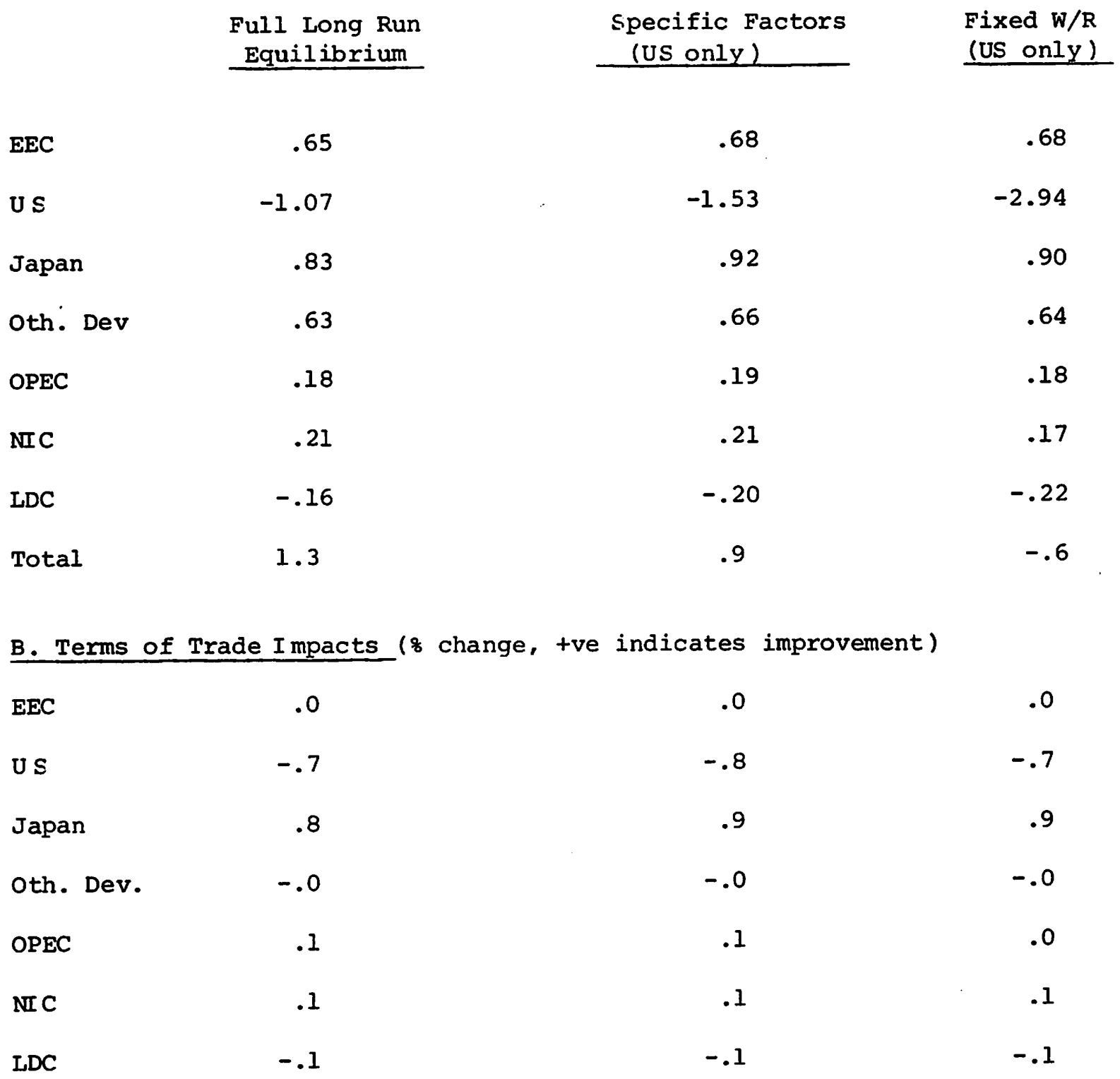


In most of the cases we consider, simple calculation of resource reallocation costs in the manner we suggest appears to reduce the net welfare gains (increase losses) of any policy change. Our calculations indicate that these costs could be substantially higher than was previously thought because labour reallocations are larger. In one case welfare gains to the . world economy result ignoring adjustment costs, but welfare losses result incorporating them. We also identify significant resource reallocations between traded and non-traded goods industries which are excluded in existing analyses of adjustment costs. In the case of a unilateral abolition of tariffs where regions are not modelled as price-takers, the presence of factor specificity or rigid wages leads to larger welfare losses than in a conventional full employment model. If existing tariffs are below optimal tariffs the terms of trade deterioration tends to be larger than under full long-run equilibrium assumptions.

While we do not suggest that any one of the alternative formulations we discuss is either dominant or most desirable in trade policy analysis, our calculations do highlight the, perhaps obvious, feature that a changed model formulation from usual long-run equilibrium analysis can lead to a changed perspective on trade policy evaluation. 
Baldwin, Robert E., Mutti, John H., and Richardson, J. David. "Welfare Effects on the United States of a Significant Multilateral Tariff Reduction." Journal of International Economics, 10 (Aug, 1980) 405-423.

Bale, Malcolm D. "Estimates of Trade - Displacement Costs for U.S. Workers." Journal of International Economics, 6 (Aug, 1976) 245-250.

Brecher, Richard "Minimum Wage Rates and the Pure Theory of International Trade." Quarterly Journal of Economics, 88 (Feb., 1974) 98-116.

Brown, F. and Whalley, J. "General Equilibrium Evaluations of Tariff-Cutting Proposals in the Tokyo Round and Comparisons With More Extensive Liberalization of World Trade." Economic Journal, 90 (Dec, 1980) 838-866.

Cline, W.R., Kawanabe, N., Kronsjö , T.O.B., and Williams, T. Trade Negotiations in the Tokyo Round: A quantitative assessment. Washington D.C: The Brookings Institution, 1978.

Deardorff, Alan V. and Stern, Robert M. "An Economic Analysis of the Effects of the Tokyo Round of Multilateral Trade Netotiations on the United States and the other Major Industrialized Countries." Report to the U.S. Subcommittee on International Trade, U.S. Government Printing Office, June 1979.

Fullerton, Don "Transition Losses of Partially Mobile Industry Specific Capital." (Forthcoming in Quarterly Journal of Economics).

Jones, Ronald W. International Trade: Essays in Theory. Amsterdam: North Holland, 1978 .

Mansur, A. Ho and Whalley, J. "Numerical Specification of Applied General Equilibrium Models: Estimation, Calibration, and Data" to appear in an N.B.E.R. Conference volume on Applied General Equilibrium Models edited by Herb Scarf and John Shoven, 1982.

Mayer, W. "Short-run and Long-run Equilibrium for a Small Open Economy." Journal of Political Economy, 82 (Sept., 1974) 955-967.

Neary, J. Peter. "Short-Run Capital Specificity and the Pure Theory of International Trade." Economic Journal, 88 (Sept., 1978) 488-510.

Neary, J. Peter. "Intersectoral Capital Mobility, Wage Stickiness and the Case for Adjustment Assistance." University of Stockholm Institute for International Economic Studies, seminar paper \#143 (May, 1980).

Whalley, John. "The North-South Debate and the Terms of Trade: An Applied General Equilibrium Approach." University of Western Ontario Centre for the Study of International Economic Relations (March, 1982). 
$\underline{1981}$

$8101 C$

$8102 C$

$8103 C$

$8104 \mathrm{C}$

$8105 C$

$8106 C$

$8107 \mathrm{C}$

8108C D SJ

8109C D SU

$8110 \mathrm{C}$

$8111 C$

$8201 C$

$8202 C$

$8203 C$

$8204 C$

$8205 C$

$8206 C$

$8207 C$

$8208 \mathrm{C}$

8209C DSU

Markusen, James R. Factor Movements and Commodity Trade as Compliments: A Survey of Some Cases.

Conlon, R.M. Comparison of Australian and Canadian Manufacturing Industries: Some Empirical Evidence.

Conlon, R.M. The Incidence of Transport Cost and Tariff Protection: some Australian Evidence.

Laidler, David. On the Case for Gradualism.

Wirick, Ronald G. Rational Expectations and Rational Stabilization Policy in an Open Economy

Mansur, Ahsan and John Whalley Numerical Specification of Applied General Equilibrium Models: Estimation, Calibration, and Data.

Burgess, David F., Energy Prices, Capital Formation, and Potential GNP

Jimenez, E. and Douglas H. Keare. Husing Consumption and Income in the Low Income Urban setting: Estimates from Panel Data in El salvador

Whalley, John Labour Migration and the North-South Debate

Manning, Richard and John McMillan Government Expenditure and Comparative Advantage

Freid, Joel and Peter kowitt Why Inflation Reduces Real Interest Rates

1982

Manning, Richard and James R. Markusen Dynamic Non- Gubstitution and Long Run Production Possibilities

Feenstra, Robert and Ken Judd Tariffs, Technology Transfer, and Welfare

Ronald W. Jones, and Douglas D. Purvis: International Differences in Response to Common External hocks: The Role of Purchasing Power Parity

James A Brander and Barbara J. Spencer: Industrial strategy with Committed Firms

Whalley, John, The North-South Debate and the Terms of Trade: An Applied General Equilibrium Approach

Roger Betancourt, Christopher Clague, Arvind Panagariya CAPI TAL UTILIZATI ON IN GENERAL EQUILIBRI UM

Mansur, Ahsan $\mathrm{H}_{4}$ On the Estimation of Import ana Export Demand Elasticities and Elasticity Pessimism.

Whalley, J. and Randy Wigle PRICE AND QUANTITY RIGIDITIES IN ADJUSTMENT TO TRADE POLICY CHANGES: ALTERNATIVE FORMULATIONS AND INITIAL CALCULATIONS

Jimenez, E. SQUATTING AND COMMUNITY ORGANIZATION IN DEVELOPING COUNTRIES : A CONCEPTUAL FRAMEWORK 